\title{
African Humanism in Achebe in Relation to the West
}

\author{
Edeh \\ Department of Philosophy, University of Abuja, Abuja, Nigeria \\ Email: pedeeh@gmail.com
}

Received 20 October 2014; accepted 24 March 2015; published 26 March 2015

Copyright (C) 2015 by authors and Scientific Research Publishing Inc.

This work is licensed under the Creative Commons Attribution International License (CC BY).

http://creativecommons.org/licenses/by/4.0/

c) (i) Open Access

\begin{abstract}
The belief system that defies or negates the existence of other beings is the one which claims superiority over other beings in existence. On the contrary, African humanism is the philosophy which naturally enables the coexistence of all humans, irrespective of their creed, culture, tribe, nation or race. Achebe expressed and $x$-rayed the displeasure in the breaking of this principle or philosophy with the intrusion and imposition of western way of life which defied the existence of the kind of tranquility that existed amongst Africans, thereby leading to all things breaking apart. This paper examined African humanism within the context of African philosophical outlook as it was yesterday, today and tomorrow in complementarity with the western humanism. It drums out a few examples from the works of Achebe as they express and relate African world view in relation to the west. The paper aims at bringing African philosophy to relevance and unifying it worldwide without which philosophy is without universal relevance.
\end{abstract}

\section{Keywords}

\section{African Humanism in African Philosophy, Complementarity, The West}

\section{Introduction}

The idea of humanism has been addressed by various scholars in various spheres of life over the years. Interestingly, it is a philosophy that has placed human race as the first thing in line of all importance. As an ethical stance, it lays an emphasis on human dignity, concerns and capabilities with particular regards to human rationality. Humanism is a word with many meanings, but its philosophical meaning can be seen when contrasted to the supernatural or appealing to higher authority.

African humanism is that ethical understanding which is enjoyed by the Africans in their way of life as depicted in all works of the father of African literature Achebe, especially in "things fall apart" (Achebe, 2002), "no longer at ease", and "there was a country" (Achebe, 2004) and works of many other African writers. Where 
African culture and traditions are shown as deeply rooted in humanism such that the extension of which brought in the western stance which invariably altered that peaceful understanding and coexistence enjoyed by the African people, as a result of varied outlook on ethical issues introduced by the white man.

Studies have historically shown that since the 19th century, the idea has been associated with anti-clericalism as a result of the 18 th century renaissance. It however took a different dimension by the 21 st century at which period humanism tends towards human rights, reproductive rights, gender equality, social justice and the separation of the church and the state. These issues cut across all human races from East, West and the entire of Africa. In Africa, it is exemplified as embedded in our culture and traditions which Achebe portrayed in characters like Okonkwo who was seen to fulfill the tradition in spite of all odds and even where he was advised in favour of humanism he did obviously to keep his pride.

This paper however examines the idea of humanism in African philosophy in the curse of history from the West to Africa. It examines the differences that exist in the West, taking a critical look at the meaning of humanism in the African context, as expressed in the works of Achebe; it evaluates and makes the differences that exist between the west and African humanism. Finally, the paper concludes with possible recommendations on African philosophy yesterday, today and tomorrow.

\section{Conceptual Analysis}

The New International Webster's dictionary (614) defines humanism as:

A system of thinking in which man, his interest and development are made central and dominant tending to exult the culture and practical rather than the scientific and the speculative.

Humanism is also viewed as a moral philosophy which places human as primary in range of importance. This suggests that the central point of humanism is humanity itself.

However, the term humanism is ambiguous since it means differently to different people who have used the word to suit their works. Nevertheless, we shall look through the works of Fredrick, who have identified a number of humanisms as it reflects in different spheres of life (Fredrick, 2014):

1) Literary Humanism: this is more or less a devotion to the Humanities or literary culture.

2) Renaissance Humanism: this refers to the spirit of learning that developed at the end of the Middle Ages with the revival of classical letters and a renewed confidence in the ability of human beings to determine for themselves truth and falsehood.

3) Cultural Humanism: is the rational and empirical Traditional that originated largely in ancient Greece and Rome, evolved throughout European history and now constitute a basic part of the Western approach to science political theory, ethics and law.

4) Philosophy Humanism: refers to outlook or way of life centered on human needs and interests. Sub-categories of this type are Christian humanism and modern humanism.

5) Christian Humanism is a philosophy advocating the self-fulfilling of man within the framework of Christian principles. Thus human oriented faith is a product of the renaissance and is a part of what made up renaissance humanism.

6) Modern Humanism: this is also known as naturalistic humanism, scientific, ethical and democratic humanism respectively. It is defined by one of its leading proponents Corliss Lamont as "a naturalistic philosophy that rejects all supernaturalism and relies primarily upon reasons and science, democracy and human compassion". This form of humanism has dual origin both secular and religious which are the sub-categories.

7) Secular Humanism: is an outgrowth of the 18th century enlightenment rationalism and 19th century free thought many of which included the council for democratic and secular humanism, and the American rationalist federation and many other wise unaffiliated academic philosophers and scientists advocate this philosophy.

8) Religious Humanism: this came as a result of ethical culture, Unitarianism and universalism. Today many Unitarian universal congregation and all ethical culture societies describes themselves as humanist in modern sense.

\section{African Humanism and Its Relation to the West}

The term African humanism is no less far in meaning from the idea of Western humanism. Nevertheless, we shall examine the idea of humanism in the African context as we shall draw some examples from across African continent by way of illustration. In drawing the meaning of African humanism we shall make references in complementarity with the western context and sporting their differences at the same time.

In southern Africa, the idea of humanism has been identified variously as Ubuntu. Ubuntu is seen as an ethical philosophy which is centered on the people's allegiances and relation with one another.

Ubuntu is a word that has its origin in the Bantu language of southern Africa. According to Desmond (1999), 
"a person with Ubuntu is open and available to others, affirming of others does not feel threatened that others are able and good". He further stressed that Ubuntu is the "essence of being human". This suggests the fact that man cannot live in isolation. To buttress this fact, Louw (1998) avers, "the concept of Ubuntu defines the individual in their several relationships with others. This explains the Zulu believe in the maxim, "Umuntu ngumuntu ngabantu" meaning "a person is a person".

Nelson Mandela explains further that Ubuntu can be seen where a person who is on a journey stops by a village on his way, he doesn't need to ask for water or food. He is given by those around on arrival.

In the phase of change the concept of Ubuntu is viewed as one of the founding principles of the new republic of South Africa this is connected to the idea of African renaissance. Ubuntu is used politically to emphasize the need for unity in consensus in decision making as well as the need for a suitably humanitarian ethics to inform those decision.

Amongst the Zimbabwe people, the concept of Ubuntu is viewed the same way. They speak shona language among the Zulu's and the same saying in shona is "munhu munhu nekuda kwevanhu". There appears a seemingly difference, the fact is "Ubuntu" is "Unhu" in shona language. Samkenge (1980) attempted a highlight of the three maxims of the "Hunhuism" or "Ubuntuism".

First, to be human is to affirm ones humanity by recognizing the humanity of others and on that basis establish respectful relations with them. Secondly, that if and when one is faced with a decisive choice wealth and the preservation of life of another human being, then one should apt for the preservation of life... thirdly, the king owed his status including all the powers associated with it to the will of the people under him.

Worthy of note is the fact that African humanism has been commonly misconceived to be a set of values brought into, instead of emerging from the communities on the African continent. This is due to the influence of modern European humanism premised upon a secular naturalism as the only model of humanism. Though the western humanist have tried to establish the fact that Christianity has come to draw human beings attention centered on human values to see point however argue that if humanism is defined as a value system which places priority on the welfare, worth and dignity of human being, it must be noted that there are also tradition in the afterlife, for they believe punishment or redemption exist only on earth. Thus, the tendency is to rely more on human action and human subjects.

Obviously, Africa is a conglomeration of many indigenous ethnics groups. Cosmologically, they have many similarities in their religious practices. According to Gordon (2005) the cosmology of the people south of the Sahara, especially the communities along the ancient lakes and plains of the Sahara-Sahalian region of northern Africa tend to have a concomitant ontology or conception of being and a system of values. In which greater realities and values are afforded to things of the past. The greater being first has the greatest ontological weight and whoever is brought into being closer in time to the moment of the origin of the world is afforded greater weight and values than one present action while the future is of no ontological relevance. Thus Gordon avers:

Indigenous Africans system affirms that human negotiate their affairs with the understanding that cannot change the past (although they can be informed by it, especially through the ancestors), are entirely responsible for the present, and must take responsibilities for their future.

This form of humanism does not require the rejection of religion but may exist alongside it. Akan humanism among the Ashanti of Ghana on the one hand, does not place the idea of Supreme Being as one who would cast evil doers into hellfire as the western God. While the western humanism sees religion as impeding the concentration of human energies on building the good society, the tension between the SupremeBeing and humanism does not appear among the Akan people. Thus, Gyekye (1995: pp. 144-145) avers:

For the Akan, religion is not seen as hindering the pursuit of one's interests in this world... Akan humanism is the consequences not only of a belief in the existence of a supreme being and other supernatural entities but more importantly I think of the desire to utilize the munificence and powers of such entities for the promotion of human welfare and happiness.

Amongst the Muslims of the northern Africa, humanism has been viewed by various Muslim scholars in various ways, Ibn Rushd (1126-1198) popularly known as Averroes among the Cordoba-Spain, is said to have argued for the secularization of political life and dominance of reason, this led to his rejection by the Muslim world. His works led Imam Mohammed Abdou (1849-1905) an Egyptian born to argue for freeing thought from convention as well as presenting a political theory of citizen's right for social justice rather than lined obedience to the religious state. Another Muslim scholar zaki Naguib Mahmoud (1905-1993) he defended the dominance of reason through logical positivism in science and based his form humanism on secular naturalism, still yet another Egyptian born adel-Rahman Badani (1917-2002) also presented his atheistic existential philosophy as more radical humanism for the Muslim world by comparing it with Sufism arguing that the human subject is prioritized. 
According to Gordon, an Algerian novelist and a historian Asia Djebar (1936) brought in nine new dimensions to the question of subjectivity and the impact of physical and historical limits. In her work, she examines the emergency of women revolutionaries under extraordinary repressive circumstances and in her novel, how reclamation of their voices and bodies exemplifies liberation women.

Modern African Humanities is an era identified to view humanism beyond the indigenous models. This came up as a result of most Africans responses to "conquest, colonization and the various slave trade along the African cost" (Gordon). Worthy of note is the fact that this involves a lot as this brought with them Christian liberal and republican values even around Muslim empires too in middle age and whose impact are been felt even today.

Modern African humanism was also addressed during the medieval African Christianity. This is found in the works of ST Augustine of Hippo (350-430) in addressing the problem of Theodicy, accounting for the presence of evil in a universe ruled by omnipotent, omniscient and benevolent God. ST. Augustine argued that human beings are responsible for evil because such actions are necessary possibility y of freedom. There are other African writers whose works are said to have become a feature of modern African humanistic thought particularly it concerns with philosophical anthropology.

African secular humanism is said to have emerged with effort of Anta Diop (1923-1986) and Leopold Sedar Senghor (1906-2001). Diop has emphasized on the historical effort of ancient Africans as the first Homo sapiens who laid grounds for cultural life of the species. Thus, the ancestral values are echoed in his works, while Senghor with Aime Cesaire (1913) founded in negritude movement which focused on the creative potential of black consciousness. Senghor is said to have defended humanity of the black Africans primarily through literature and reflections in music. He further argued that African value system were more humanistic than the Europeans, because the African models have found that the passionate or emotional side of a person carries the same values and legitimacy as the rational analytic side.

Kwame Nkrumah (1909-1972) in 1946 offered what he called "Consciencism", for him African humanism was a call for explicit political responses to social problems.

In the same vain Frantz Fanon (1923-1961) diagnosed a sick modern world premised upon human actions were in the tax of faced by contemporary Africans was to build up their material infrastructure base on national consciousness in other to transform negative cultural symbols into positive ones to set humanity right. There are so many African humanists this is just to mention but a few. It must be noted here that the two influential secular humanism that emerged focused on the question of consciousness.

Finally, the emergence of academic intellectuals set the stage for secular African humanism. Thus in recent time many African scholars have sort this issues through the disciplinary perspective of philosophy, political theory, political economy and many others. I will not fail to mention the place of musical poeticist humanist whose place is famous in "world music" and whose artist come from all parts of Africa and represent nearly all his traditions. Hismusic serves as a critical commentator on Africa's contemporary issues he is the Nigerian Fela, Anikulapo Kuti (1938-1997).

\section{Achebe and Humanism}

Though some western scholars like Purvey had criticized Achebe from being seen as a humanist in his writings, but his criticism the author feel is born of racial discrimination and the imperialist mind that nothing good comes from the black race.

One basic aspect we must all acknowledge in Achebe as an African humanist is the fact that he chose to give out what he knows that the world may learn and understand for posterity. This act has been depicted in all encomium showered over his singular book that has been translated in so many languages for people of Africa the West, Asian and Africans in the Diaspora.

The setting of the book "things fall apart" is a vivid setting of African way of life. Before the arrival of the white man Africans have lived in peace as they encourage one another in life. Part of the way in which Africans live possibly made "Unoka" Okonkwo's father to be a weekly which also lead to the development of Okonkwo to live a life above his father. This also explains why Africans strongly believes that a child shall grow higher than the father.

Achebe x-rayed humanism in the character of Okonkwo in the adoption of the young lad Ikemefuna who grew under his roof to call him father. Ikemefuna was very much loved by his foster father. That he was killed by Okonkwo bedevils ethical and naturalistic fallacy. What is important to our studies here is that humanism thrives at a time and to the point that Okonkwo was even given a cautionary word by his best friend saying "this child calls you father do not have hand in his death" this is an act of humanism which is not far from the west.

That Ikemefuna was slew by his father is nothing barbaric as different from all traditions of the world. Even 
in the holy books this practices abound as depicted in the demands of God of the father of faith (Abraham) to offer his only son. God himself so loved the world that he offered his only begotten son to be sacrificed through crucifixion a very shameful death on a cross.

In the book "there was a country", Achebe talked about a teacher who happened to be the pillar of his people as many of us are even now as I speak. He expresses the frustration of his difficulty to convey how important such teachers were, "particularly as that is no longer the case today".

This "Okongwu" as he was called, was a generous man and sponsored a number of children in various schools in Nigeria and abroad. In time past in the history of this country, there existed men like Okongwu who had means, sent family members abroad to advance their education with the hope that they would return and improve the standard of living of their family and community.

This is a clear picture of a caring and committed teacher, a person dedicated to his family and the entire community, worthy of note. An example of such teachers abounds in African communities. They were treated with reverence by both adults and children. Such a teacher was an epitome of African humanism.

In his work "no longer at ease," Obi Okonkwo's act of demanding or accepting of bribe is an aberration to African humanism. For it is an African way of life to go an extra mile to help a stranger who he knows not where he comes from. This explains the hospitality extended to the white man when he came to Africa and he refused to go. Rather he chose to give Africans funny names and still from her natural and human resources which he took away as slaves. Living them with the book of life (Bible \& Qu'ran) with a bunch of contradictions as they only represent the life culture and traditions of other nations of the white race.

\section{Evaluation and Conclusion}

This paper has so far examined humanism, giving its meaning from the view that it is a philosophy that has placed man (human being) as the first thing in the line of importance. Though it sounds ambiguous ab-initio, philosophically its meaning can be drawn from the super natural or the higher authority for the well being of mankind. African humanism is not far in meaning from western humanism. They only differ in few varied ways, especially in terms of religions.

Historically, Achebe can be likened to Hammer of the Greek Roman, who has laid a foundation for Greek literary tradition. He can also be likened to Pushkin, regarded as Russian father of literature; Achebe is African Shakespeare (Nwala, 2013).

As Nwala rightly pointed out, these were the men of comparable status in history of human civilization. As Africans, we should begin to see Achebe in a like manner if we have not.

Nwala described Achebe as "a teacher, a great philosopher and a great humanist. He was an idol and a symbol, which we all hoisted for the guidance of the civilization of our youth".

He must have been a man with resilient spirit, and a man of history and destiny.

Beyond this, what makes him a humanist is the question that has motivated me to write. Indubitably, you will agree with me that Africa is in great need of a spiritual rebirth, especially now that so many African countries are in crises. There is a need to reproduce the caliber of the teacher Achebe reminding us of, whose lifestyle exhibits the loving and caring attitude that Africans refer to as "mutunchi" in hausa, "onghinyiehie" in Igede language, "mmadu" in Igbo, "Omoluabi" in Yoruba and "ubuntu" among the southern Africa.

Scholars like Reuel referred to African Humanism as a Compass which was "savaged by European colonialism and overzealous missionaries with their racism" (Reuel, 2014). He further noted that consequent to such destruction, Africans were disabled from teaching Ubuntu formally in schools, colleges and universities in Southern Africa.

It is perennial therefore to institutionalize African humanism in all institutions of learning from primary to university level. This also implies the teaching of undistorted African history, African sociology, African philosophy and African culture throughout informal and formal education. By so doing Africa will turn from crisis to creativity, and from poverty to success. This is achievable not by magical formula, but because Africans will realize that our ancestors keep poverty at bay because "community" to them means "solidarity".

Achebe displayed a historic writing for when going through his works and cast your mind back to the culture and tradition of your people; you will agree with me that it create the feeling of greatness amongst our ancestors. Mazisi Kunene echoed this in a Zulu Epic, the Emperor Shaka the Great where he avers that our ancestors preferred the "power of humanity and kindness" to prevail in their land as opposed to the cruelty they had seen in the conduct of Europeans.

Regrettably the Europeans had derogatively regarded African ancestors as "uncivilized" while theirs are saints we revere and change our names for in baptism today. Traditional African culture regarded it as everyone's duty to ensure that no human being was subjected to humiliating poverty while others had surplus. 
What this means is that instead of looking to the West or East to find solutions to our debilitating situation, we need not look beyond our ancestral traditions. We need to celebrate the values that made our ancestors the great people they were.

Thus Achebe needs to be celebrated for even as he has joined our ancestors he lives more with us today and ever as long as his works remains. As such I lean my voice with Nwala to say that, Achebes death is only a transition,

but what Achebe represents in history, what he means to every one of us, our people, Nigeria, Africa and the world cannot die. He is immortal, we may be missing his physical presence, but Achebe is all over us in our culture, our civilization, our thinking and our values.

Finally, we must conclude by saying that Chinua Achebe is an epitome of African humanism as he has shown in all his works. Achebe's works are a Clarian call for Africans to look within to see what God has endowed in us. The potentials in Africa abounds both in human and natural resources. Africa has all it takes to rule the world. Africa was the original Garden of Eden these facts were hidden from us. I have done some work to proof these facts. For if the Garden of Eden was to be anywhere in Europe or America it would have been a tourist zoo today.

Africa had extend a hand of humanism to the Europeans but they extended cruelty and sharp practices in return and they have set us against ourselves as imbibing their culture and tradition have lead to our culture and tradition to tear apart and our peaceful center no longer holds.

We seek to rediscover the values that will make us the people we want to become: the agents of African ancestral vision, that of Africans giving the world a humankind face today and tomorrow. Thus the future of African philosophy depends on our efforts to recall the past ancestral great thoughts and make present of them in our dealings with humanity. For instance; the principles of ontological boomerang effects as expressed in Igbo philosophy "Egbebere, ugobere, onyesinaibeya e bena, nkukwaya". Meaning "let the eagle perch and let the kite perch he who deprives the other to perch let him lose his wings".

The west has a great role to play to help restore confidence in African philosophy by accepting African world view on the merits of their logical an epistemic value which the west must understand and come to terms with philosophically. This must be done within the principles of compementarity. The west must accept the fact that being exists in "mutual complementary dependence" and the failure of Africa is due to western influence which defies this principle. This explains why Africa has always failed politically, economically, technologically socialy and even religiously. Because it is not as simple to set aside ones natural guiding principles to imbibe in another's without proper guidance and reasons. The future of African philosophy is greatly dependent on mutual comlementarism with the west. And if philosophy must be seen as defined by this conference to have a universal meaning then the future of philosophy universally shall imbibe the philosophy of complementarism as expressed in Asuzu (2007: p. 39) avers:

... Missing links are bound to each other in the form of entities that have mutual right to serve each other... These rights are such that a negation of them is practically the same as a negation of the being of those who are supposed to have such rights.

\section{References}

Achebe, C. (2002). Things Fall Apart. Ibadan: William Heinemann Educational Books, Nazareth Press.

Achebe, C. (2004). There Was a Country: A Memoir.

http://www.amazon.com/There-Was-Country-A-Memoir/dp/014312403X

Asuzu, I. I. (2007). Ibuanyidanda (pp. 39). UK: Transaction Publishers.

Desmond, T. (1999). No Future without Forgiveness. Image Books.

Fredrick, E. (2014). http://infidels.org/library/modern/fred edwords/humanism.html

Gordon, R. L. (2005). Humanism Africa. New Dictionary of History of Ideas. Encyclopedia.com 10th April 2010.

Gyekye, K. (1995). An essay on African Philosophical Thought: The Akan Conceptual Scheme (pp. 144-145). rev. ed. Philadelphia Temple a University Presses.

Louw, D. J. (1998). Ubuntu: An African Assessment of Religious Order. Twentieth World Congress of Philosophy.

Nwala T. U. (2013). Achebe Was a Teacher, Philosopher, Humanist (p. 17). Guardian Sunday, 24 March 2013. From Nkechi Onyedika, Abuja Sunday Magazine-Arts.

Reuel, K. (2014). Attuned leadership: African Humanism as Compass. http://www.reuelkhoza.co.za/attunedleadership.htm

Samkenge, S. S. (1980). Hinduism or Ubuntuism: A Zimbabwe Indigenous Political Philosophy. Location: Salisbury Graham Publishing. 